\title{
Assessment of Heat Hazard during the Polymerization of Selected Light-Sensitive Dental Materials
}

\author{
Maciej Janeczek, ${ }^{1}$ Katarzyna Herman, ${ }^{2}$ Katarzyna Fita, ${ }^{2}$ \\ Krzysztof Dudek, ${ }^{3}$ Małgorzata Kowalczyk-Zając, ${ }^{2}$ Agnieszka Czajczyńska-Waszkiewicz, ${ }^{2}$ \\ Dagmara Piesiak-Pańczyszyn, ${ }^{2}$ Piotr Kosior, ${ }^{2}$ and Maciej Dobrzyński ${ }^{2}$
}

\author{
${ }^{1}$ Department of Biostructure and Animal Physiology, Wroclaw University of Environmental and Life Sciences, Kożuchowska 1, \\ 51-631 Wroclaw, Poland \\ ${ }^{2}$ Department of Conservative Dentistry and Pedodontics, Wroclaw Medical University, Krakowska 26, 50-425 Wroclaw, Poland \\ ${ }^{3}$ Faculty of Mechanical Engineering, Technical University of Wroclaw, Eukasiewicza 5, 50-371 Wroclaw, Poland
}

Correspondence should be addressed to Maciej Dobrzyński; maciej.dobrzynski@umed.wroc.pl

Received 24 June 2016; Revised 21 September 2016; Accepted 21 September 2016

Academic Editor: Davor Zeljezic

Copyright (C) 2016 Maciej Janeczek et al. This is an open access article distributed under the Creative Commons Attribution License, which permits unrestricted use, distribution, and reproduction in any medium, provided the original work is properly cited.

\begin{abstract}
Introduction. Polymerization of light-cured dental materials used for restoration of hard tooth tissue may lead to an increase in temperature that may have negative consequence for pulp vitality. Aim. The aim of this study was to determine maximum temperatures reached during the polymerization of selected dental materials, as well as the time that is needed for samples of sizes similar to those used in clinical practice to reach these temperatures. Materials and Methods. The study involved four composite restorative materials, one lining material and a dentine bonding agent. The polymerization was conducted with the use of a diode light-curing unit. The measurements of the external surface temperature of the samples were carried out using the Thermovision ${ }^{\circledR 5} 50$ thermal camera. Results. The examined materials significantly differed in terms of the maximum temperatures values they reached, as well as the time required for reaching the temperatures. A statistically significant positive correlation of the maximum temperature and the sample weight was observed. Conclusions. In clinical practice, it is crucial to bear in mind the risk of thermal damage involved in the application of light-cured materials. It can be reduced by using thin increments of composite materials.
\end{abstract}

\section{Introduction}

Light-cured materials are commonly used in dental treatment. The polymerization process takes place by activating a photoinitiator present in dental resin by using a lightcuring unit. At present, a quartz-tungsten halogen (QTH) or a light-emitting diode (LED) light-curing units are used. Less popular solutions include the plasma-arc-source-PAC or the argon laser. Halogen lamps emit waves which are 360$560 \mathrm{~nm}$ in length, and the radiation flux density, also called light intensity of the majority of devices, ranges from 700 to $800 \mathrm{~mW} / \mathrm{cm}^{2}$ although in some cases it exceeds $1500 \mathrm{~mW} /$ $\mathrm{cm}^{2}$. When compared with QTH, LED light-curing units are more efficient and they use less energy. The older generation of diode photopolymerization units emit light of wavelengths of approximately $468 \mathrm{~nm}$ which is of central importance for classical photoinitiators such as camphorquinone which are contained in the materials. The newer generation of LED (polywave) emits wavelengths of wider spectra (from 460 to $410 \mathrm{~nm}$ ), as a result of which it is also effective for alternative photoinitiators [1-3].

Undoubtedly, introducing light-cured materials in clinical practice was a milestone in dentistry. However, these materials are not flawless. One of their drawbacks is the polymerization shrinkage which may result in marginal leakage of the restoration. In order to minimize the risk of the shrinkage, the composition of the materials is modified, special application techniques are introduced, and alternative light-curing techniques are recommended; for example, softstart, pulsation, or pulsation soft-start are used. Another 
significant issue is a temperature increase during polymerization process. On the one hand, it results from the curing unit emitting light energy; on the other hand, it is linked with the heat generated during the exothermic reaction $[2$, $4,5]$. It has been established that dentine has good insulation properties thanks to which the pulp tissue is protected from overheating [6]; however, many researchers emphasize the risk of its occurrence, particularly in deep cavities [7-12]. A temperature increase of $5.5^{\circ} \mathrm{C}$ may already cause tissue damage [13]. It has been determined that the threshold temperature value at which irreversible disturbances of the pulp circulation are initiated is $42.5^{\circ} \mathrm{C}[14,15]$. Therefore, it can be speculated that speed and duration of thermal stimulus as well as the extent of temperature rise play an important role in pulp damage and gradual temperature increase may raise the threshold temperature higher than $5.5^{\circ} \mathrm{C}$.

The measurements of the temperature changes which occur in the light-cure materials during the polymerization process can be carried out by applying various methods, for example, using thermocouples [16-18] or thermography $[19,20]$. The values of the temperature changes observed by different authors varied considerably, since they depended not only on the method of measurement but also on many other factors, such as the location of the measurement, the type and shade of the material, and the thickness of the lightcured increment.

The aim of this study was the comparative assessment of the maximum temperature rise and the duration of polymerization process of selected light-cured dental materials, as well as the analysis of the influence of their volume on thermal parameters. The hypothesis of this study predicts that the dangerous increase in temperature during the polymerization of light-cure composite materials has negative consequence for pulp vitality.

\section{Materials and Methods}

The following light-sensitive dental materials were involved in the study:

\section{Composite Restorative Materials}

(i) Te-Econom (hybrid, Ivoclar Vivadent, Schaan, Liechtenstein)

(ii) Filtek Supreme XT (nanofil, 3M ESPE, St. Paul, MN, USA)

(iii) Tetric EvoCeram (nanohybrid, Ivoclar Vivadent, Schaan, Liechtenstein)

(iv) Gradia Direct (microhybrid, GC Corp, Tokyo, Japan)

\section{Lining Material}

(i) Ionosit (compomer, DMG, Hamburg, Germany)

\section{Bonding Agent}

(i) ExciTE (V generation, Ivoclar Vivadent, Schaan, Liechtenstein).
TABLE 1: Types of materials, sample sizes, sample maximum temperature $T_{\max }$, and time of reaching maximum temperature $t_{\max }$ ( $m$ : mass, $d$ : diameter, $h$ : height, and $l$ : the distance between the polymerization unit and the sample).

\begin{tabular}{|c|c|c|c|c|c|c|}
\hline Material & $\begin{array}{c}m \\
(\mathrm{mg}) \\
\end{array}$ & $\begin{array}{c}h \\
(\mathrm{~mm})\end{array}$ & $\begin{array}{c}d \\
(\mathrm{~mm})\end{array}$ & $\begin{array}{c}l \\
(\mathrm{~mm})\end{array}$ & $\begin{array}{l}T_{\max } \\
\left({ }^{\circ} \mathrm{C}\right)\end{array}$ & $\begin{array}{c}t_{\max } \\
(\mathrm{s})\end{array}$ \\
\hline \multirow{5}{*}{ Te-Econom A-1 } & 70 & 2 & 4 & 0 & 40.5 & 7.6 \\
\hline & 70 & 2 & 4 & 3 & 39.2 & 8.2 \\
\hline & 150 & 5 & 4 & 0 & 39.8 & 17.5 \\
\hline & 220 & 2 & 8 & 0 & 43.5 & 10.6 \\
\hline & 520 & 5 & 8 & 0 & 52.5 & 20.6 \\
\hline \multirow{2}{*}{$\begin{array}{l}\text { Filtek Supreme XT } \\
\text { A-1B }\end{array}$} & 120 & 5 & 4 & 0 & 39.2 & 17.0 \\
\hline & 490 & 5 & 8 & 0 & 41.3 & 23.4 \\
\hline $\begin{array}{l}\text { Filtek Supreme XT } \\
\text { A-3B }\end{array}$ & 219 & 2 & 8 & 0 & 46.8 & 22.5 \\
\hline \multirow{5}{*}{$\begin{array}{l}\text { Filtek Supreme XT } \\
\text { A-1D }\end{array}$} & 69 & 2 & 4 & 0 & 31.4 & 9.3 \\
\hline & 71 & 2 & 4 & 0 & 36.7 & 43.0 \\
\hline & 123 & 5 & 4 & 0 & 37.1 & 49.8 \\
\hline & 200 & 2 & 8 & 0 & 41.0 & 14.0 \\
\hline & 200 & 2 & 8 & 3 & 40.8 & 14.4 \\
\hline $\begin{array}{l}\text { Filtek Supreme XT } \\
\text { A- } 4 \mathrm{D}\end{array}$ & 200 & 2 & 8 & 3 & 44.2 & 49.0 \\
\hline \multirow{2}{*}{$\begin{array}{l}\text { Filtek Supreme XT } \\
\text { A-1E }\end{array}$} & 68 & 2 & 4 & 3 & 36.4 & 10.0 \\
\hline & 200 & 2 & 8 & 3 & 42.2 & 14.2 \\
\hline \multirow{6}{*}{ Tetric EvoCeram } & 69 & 2 & 4 & 0 & 31.1 & 22.9 \\
\hline & 70 & 2 & 4 & 3 & 34.2 & 11.4 \\
\hline & 140 & 5 & 4 & 0 & 38.5 & 21.8 \\
\hline & 220 & 2 & 8 & 0 & 42.1 & 10.0 \\
\hline & 210 & 2 & 8 & 3 & 39.3 & 43.1 \\
\hline & 500 & 5 & 8 & 0 & 44.8 & 40.4 \\
\hline \multirow{6}{*}{ Gradia Direct A-3 } & 60 & 2 & 4 & 0 & 36.8 & 44.6 \\
\hline & 60 & 2 & 4 & 3 & 36.1 & 49.6 \\
\hline & 92 & 5 & 4 & 0 & 51.6 & 41.4 \\
\hline & 170 & 2 & 8 & 0 & 55.5 & 41.9 \\
\hline & 172 & 2 & 8 & 3 & 62.5 & 42.0 \\
\hline & 380 & 5 & 8 & 0 & 64.3 & 39.7 \\
\hline \multirow{2}{*}{ Ionosit } & 18 & 0.1 & 2.7 & 0 & 34.3 & 13.3 \\
\hline & 19 & 0.1 & 3.0 & 2 & 35.4 & 12.9 \\
\hline \multirow{3}{*}{ ExciTE } & 22 & 0.1 & 6.0 & 0 & 30.2 & 3.1 \\
\hline & 21 & 0.1 & 5.0 & 2 & 42.2 & 4.3 \\
\hline & 22 & 0.1 & 5.5 & 5 & 39.4 & 4.9 \\
\hline
\end{tabular}

E: enamel, D: dentine, and B: body.

The complete list of materials of various translucency and color intensity, as well as the size of the samples and polymerization conditions, is shown in Table 1 . The research was conducted with the use of the Elipar II LED (3M ESPE) light-curing unit that emits waves of $400-515 \mathrm{~nm}$ in length, with the maximum light intensity of $800 \mathrm{~mW} / \mathrm{cm}^{2}$. The composite materials were light-cured by the polymerization unit for $40 \mathrm{~s}$, lining material $-20 \mathrm{~s}$, and bonding agent $-10 \mathrm{~s}$. Samples of dental restorative materials were prepared in 


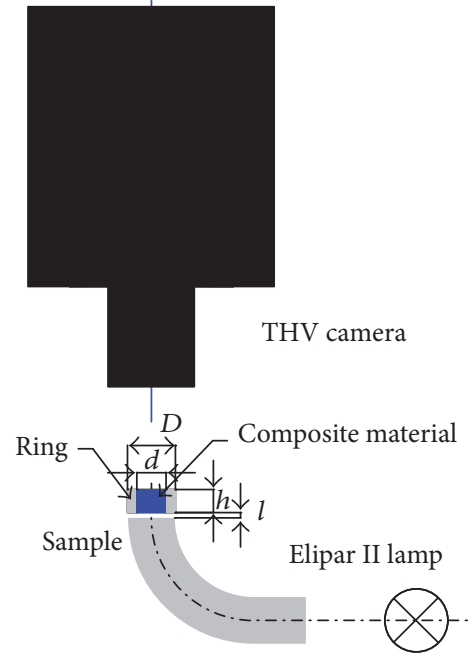

End of the optic fiber

Figure 1: Measurement system diagram. form of cylinders which filled Teflon rings of various height $(h)$ and internal diameter $(d)$ and the external $D=10 \mathrm{~mm}$ (Figure 1). Samples of bonding agents and lining materials were placed on $0.5 \mathrm{~mm}$ thick transparent PC plates with the use of a pipette. Constant temperature measurement of the external surface of the samples was carried out using the Thermovision 550 thermal camera in an isolated, dark, and air-conditioned laboratory. The measurements were taken at a distance of $45 \mathrm{~mm}$ with the use of a wide-angle lens and a distance ring. As a result, thermograms in which samples fulfilled approximately $35 \%$ of the picture area were obtained.

The prepared samples were placed at an $l$ distance from the tip end of the lamp optical fiber which was placed opposite the lens of the thermal camera. The $l$ value was 0 or $3 \mathrm{~mm}$. After the temperature of the sample has set at the level of approximately $24^{\circ} \mathrm{C}$, the light-curing unit initiating the polymerization process and the program managing the acquisition of data from the thermal camera were simultaneously activated [21]. The measurements of the heat generated in the polymerization process were taken until the maximum temperature of the sample fell below $30^{\circ} \mathrm{C}$ (Figure 2).

The strength and direction of the relationship of the maximum temperature reached by the samples in the polymerization process, as well as their weight, were determined by calculating the value of the $r$ Pearson correlation coefficient. The Kruskal-Wallis test was used to verify the hypothesis of lack of significant differences between the maximum temperature $T_{\max }$ and the time of reaching $t_{\max }$ and the type of material. The calculations were made with the use of the STATISTICA version 12 software.

\section{Results}

Examples of thermograms prepared at selected moments of the polymerization process of the Gradia Direct material samples (shade A-3) are shown in Figure 2. The maximum temperature values and the time of reaching them varied

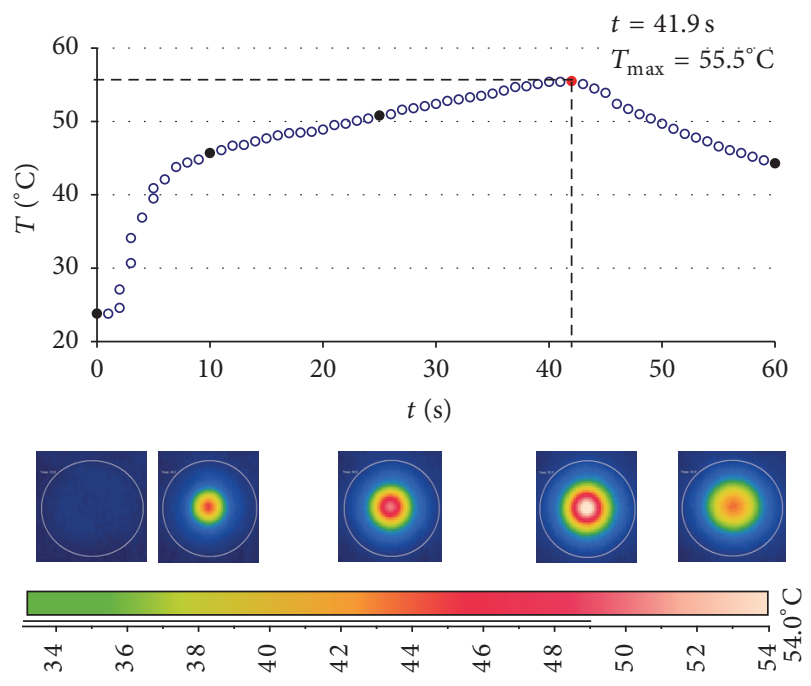

FIGURE 2: Example of temperature change in the Gradia A-3 sample ( $m=170 \mathrm{mg} ; h=2 \mathrm{~mm} ; d=8 \mathrm{~mm})$.

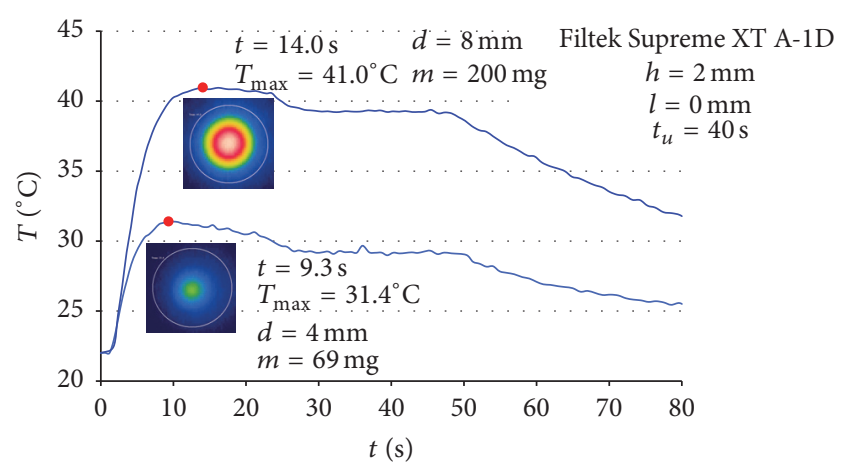

FIgURE 3: Example of temperature change during the polymerization of samples of Filtek Supreme XT A-1D of various weight and the time of exposure to the light of the light-curing unit: $t_{u}=40 \mathrm{~s}$.

depending on the weight (Figure 3) and shade (Figure 4) of a given material.

The differences between the maximum temperatures reached during polymerization by some materials were statistically significant $(p<0.05)$. The post hoc test (multiple comparisons) confirmed that an average temperature $T_{\max }$ for Gradia Direct A-3 samples was significantly higher than that for Ionosit samples (51.5 versus 34.3; $p=0.049$ ) (Figure 5). The differences between the time of reaching the maximum temperatures by some materials were also statistically significant $(p<0.01)$. The post hoc test confirmed that an average time $t_{\max }$ for samples made of Gradia Direct A-3 was considerably longer than that for samples made of Te-Econom A-1 (42.0 versus 10.6; $p=0.009$ ) (Figure 6) and ExciTE (42.0 versus $4.3 ; p=0.005$ ).

A statistically significant positive correlation between the maximum temperature and the sample weight was observed (Figure 7). In some cases, placing the tip of the optic fiber at the shortest possible distance to the sample $(l=0)$ led 


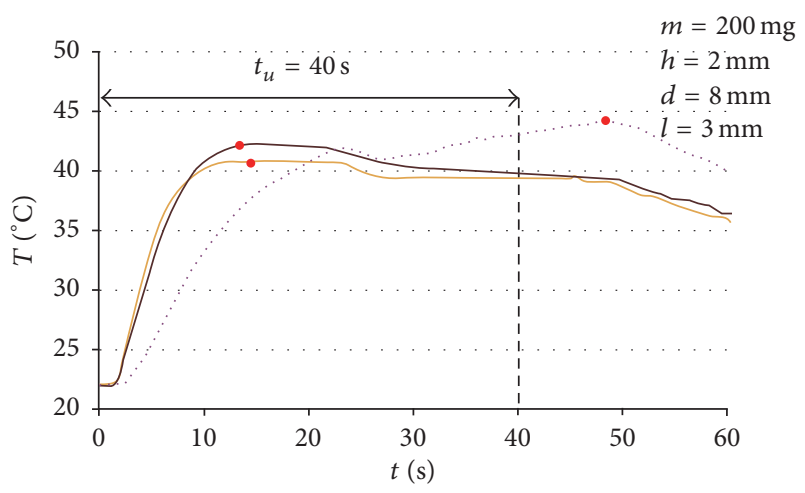

Filtek Supreme XT

- A-1D

$-\mathrm{A}-1 \mathrm{E}$

…. A- $4 \mathrm{D}$

Figure 4: Temperature changes during the polymerization of samples of Filtek Supreme XT of various shades.

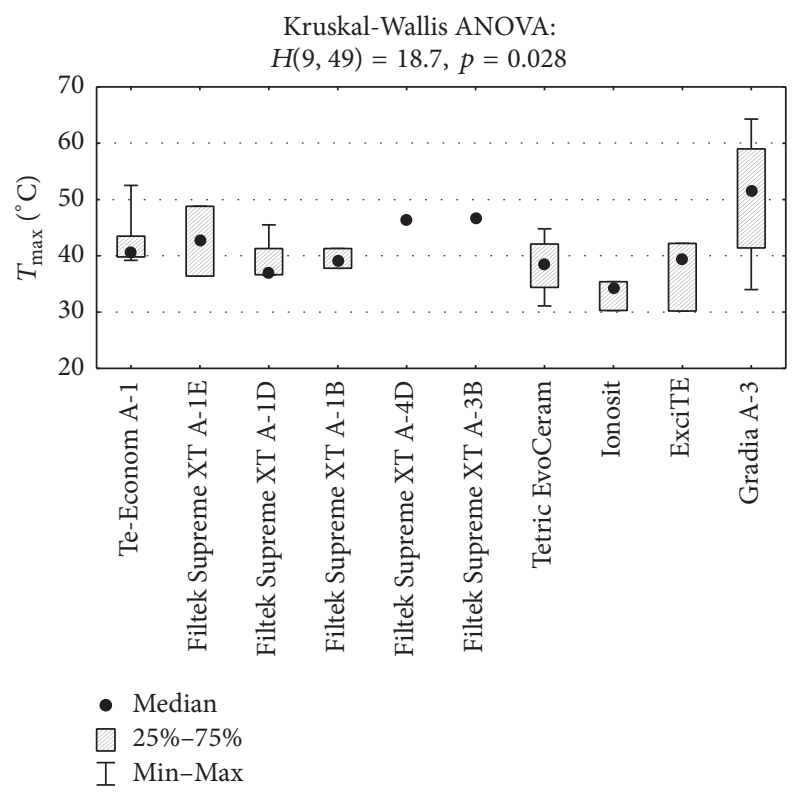

FIgURE 5: Comparison of the maximum temperature $\left(T_{\max }\right)$ of the examined materials and the Kruskal-Wallis test result.

to a dangerous increase in temperature. Placing the tip of the optic fiber in a $3 \mathrm{~mm}$ distance and reducing the sample weight resulted in the maximum temperature increments being reduced to safe values (Table 1).

\section{Discussion}

In all examined materials, the maximum temperature was positively correlated with the sample weight. Temperature increase and the time of reaching the maximum temperature also differed depending on the type of the material, its shade, and, to some extent, the distance from the curing unit. According to own research, samples with the Jonosit lining

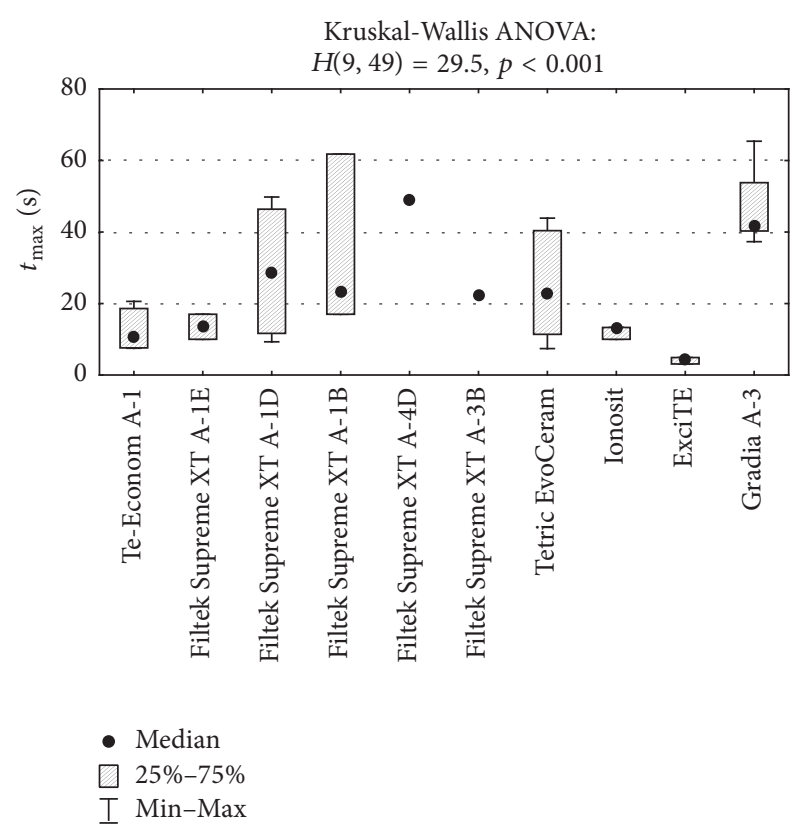

FIGURE 6: Comparison of time of reaching the maximum temperature $\left(t_{\max }\right)$ during polymerization of the examined materials and the Kruskal-Wallis test result.

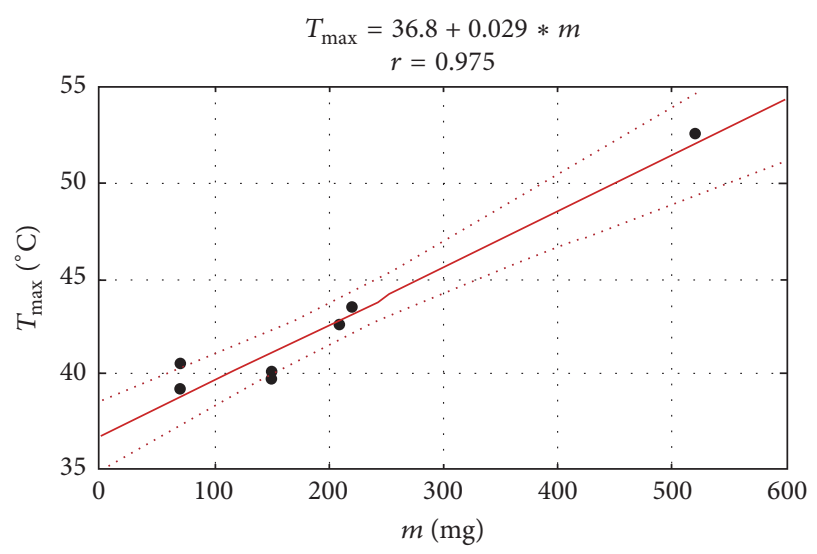

FIGURE 7: Example of a correlation diagram between the maximum temperature and the weight of a sample made of Te-Econom A-1.

compomer and the ExciTE bonding agent did not cross the threshold of $42.5^{\circ} \mathrm{C}$. When examining bonding agents of various generations applied in deep cavities, Khaksaran et al. [22] came to similar conclusions and they determined that the light-curing time for those materials followed in clinical practice, that is, $20 \mathrm{~s}$, did not lead to any dangerous increase in temperature. It is an extremely essential conclusion, as the technique of working with a composite material requires placing the bonding agent directly on the dentine, in many cases in close proximity of the pulp.

The most considerable increase in temperature, that is, above $42.5^{\circ} \mathrm{C}$, for samples weighing above $60 \mathrm{mg}$, was observed for a microhybrid material Gradia Direct. Crossing the $42.5^{\circ} \mathrm{C}$ threshold was also observed in the case of other 
examined composite materials; however, it only occurred in heavier samples of more than $200 \mathrm{mg}$. Small samples measuring around $2 \times 4 \mathrm{~mm}$ did not reach the temperature of $42.5^{\circ} \mathrm{C}$ for any of the examined materials. Single-time light curing of large amount of composite in a dental cavity may result in generating heat in an amount which may be harmful for the dental pulp. It is particularly risky in the case of the first layer of the material placed in a deep cavity. Similar conclusions were drawn by Kim et al. [23]. Interesting data were gathered by Chang et al. [19] who observed a significantly higher temperature inside the sample at the depth of 1-3 mm in comparison with the deeper layers and the external surface of the material. The authors suggest that the thickness of a light-cured layer cannot exceed $3 \mathrm{~mm}$, as polymerization in the deeper layers may not be sufficient due to a deficient amount of light. Therefore, in order to protect the dental pulp from overheating and, at the same time, to ensure optimum polymerization, it is crucial to apply proper volumes of light-cured materials.

The results obtained by other authors confirm the differences in the changes of temperature depending on the type of material [4, 6, 16, 17]. Al-Qudah et al. [6] demonstrated the highest increase in temperature for flowable composites, hybrid composites, compomers, and composites with increased density (condensable), respectively. In the research conducted by Hubbezoglu et al. [4], the highest temperature was observed for ormocers and flowable composites and the lowest for nanofil ones. However, in no case was the critical temperature value for pulp exceeded. According to the authors, the unique structure of every type of material, as well as the content and type of filler and resin, has a significant influence on the amount of heat generated in the course of polymerization. This thesis is supported by Dąbrowski et al. [11] who observed an increase in temperature that might be dangerous for the dental pulp during polymerization of a material which contains epoxy resins. A considerable increase in temperature may also occur in the case of recently introduced composite materials, such as bulk-fill. Their advantage is reduction of clinical application time due to a possibility of placing thicker increments. However, it involves a risk of overheating the pulp, particularly in deep, extensive cavities [17]. According to Dąbrowski et al. [10], not only the maximum increase in temperature after the lightcuring of a given material but also the curing time needed for it is significant. A significant amount of heat cumulated over a short period of time may be particularly dangerous for the pulp tissue. Based on own research, considerable high values of maximum temperatures were observed in multiple heavier samples over short periods of time.

The differences between the parameters in question were also observed among various shades of the same dental material (Filtek Supreme XT). The lightest shades, A-1E (used for enamel restoration) and A-1D (for dentine restoration), reached the maximum temperature within around $14 \mathrm{sec}-$ onds; higher temperature of $42.2^{\circ} \mathrm{C}$ was observed in the case of $\mathrm{A}-1 \mathrm{E}$. The darker shade (A-4D-dentine) reached the maximum temperature of $49^{\circ} \mathrm{C}$; however, it lasted longer, that is, $44.2 \mathrm{~s}$. All the compared samples were large and they weighed $200 \mathrm{mg}$ each.
Zaborowski et al. [24] obtained ambiguous results: in the case of one composite material, the most significant increase in temperature was observed for the lightest shade and for the other two materials, for the darkest one. The differences of the temperature increments that depended on the shade of the material used were also observed by other authors [20].

The increase in the temperature of a material may also depend on the light-curing unit operation mode. The authors of this study used the standard operation mode which guarantees light emission with constant intensity. According to Hubbezoglu et al. [4], the most statistically significant highest temperature was generated when using the softstart program, and the lowest was when using the pulsation operation mode. Both light-curing variants are used in order to reduce the polymerization shrinkage of materials. However, in no case did the increase in the temperature of the dentine exceed the value which had been determined as critical for the pulp $\left(5.5^{\circ} \mathrm{C}\right)$. Chang et al. [19], in turn, did not demonstrate any significant differences in the increase in temperatures after applying various light-curing operation modes. Changes in temperature during polymerization are also influenced by the type of equipment used. Monowave light-emitting diode generates less heat in comparison to the halogen one $[2,11,25]$. Due to the high light intensity, the new generation of LED curing units produce the same heat as QTH, and similarly to QTH, they have incorporated filters. The argon laser has been reported to be an even safer solution in this regard [26].

Therefore, it can be stated that an increase in the temperature of light-sensitive materials in the polymerization process is influenced by many factors which depend on both the material itself and the type of light-curing unit used. The amount of energy applied together with the beam of light depends on the time of exposure, the distance between the tip of the optical fiber and the material, the type of device used, the light-curing operation mode, the light intensity, and the light wavelength. The amount of heat generated in a given material depends on its composition, the thickness of the polymerized layer, and its shade $[4,6,8,11,14,18,20,24$, 27]. Consequently, the final increase in temperature during polymerization is a derivative of many factors. In clinical practice, the thickness of the dentine layer that separates the material from the pulp is also crucial, as the dentine layer is an important protective barrier against transmitting too much heat into the pulp chamber.

\section{Conclusions}

Dentists should be aware of the potential risk involved in the use of light-sensitive dental materials. In order to minimize it, it is necessary to follow the recommendations and instructions of the manufacturers of particular dental materials and photopolymerization units, as well as to apply appropriate volumes of these materials. One needs to be particularly cautious when restoring deep cavities, as it involves the most significant risk of overheat. This process may result in posttreatment hypersensitivity or even irreversible inflammation or dental pulp necrosis. 


\section{Competing Interests}

The authors declare that there is no conflict of interests regarding the publication of this paper.

\section{Acknowledgments}

This project is supported by Wroclaw Centre of Biotechnology and The Leading National Research Centre (KNOW) programme, for years 2014-2018. The research was supported by statutory research and development activity funds assigned to Faculty of Veterinary Medicine, Wroclaw University of Environmental and Life Sciences.

\section{References}

[1] J. M. Powers and J. C. Wataha, Dental Materials. Properties and Manipulation, Elsevier Urban \& Partner, Wrocław, Poland, 2013 (Polish).

[2] K. Dudzik and E. Iwanicka-Grzegorek, "Light curing units used in dentistry-kinds, application and mechanism of the polymerization," Nowa Stomatologia, vol. 4, pp. 122-127, 2009 (Polish).

[3] F. Bayindir, N. O. Ilday, Y. Z. Bayindir, O. Karataş, and A. Gurpinar, "Color changes in resin cement polymerized with different curing lights under indirect restorations," Journal of Conservative Dentistry, vol. 19, no. 1, pp. 46-50, 2016.

[4] I. Hubbezoglu, A. Dogan, O. M. Dogan, G. Bolayir, and B. Bek, "Effects of light curing modes and resin composites on temperature rise under human dentin: an in vitro study," Dental Materials Journal, vol. 27, no. 4, pp. 581-589, 2008.

[5] P. Grodecki and A. Olszewski, Wpływ źródła światła na wzrost temperatury polimeryzacji materiałów kompozycyjnych stosowanych do wypełniania ubytków zębów, W: Termografia i termometria w podczerwieni, TTP 2002, V Konferencja krajowa, Ustroń-Jaszowiec, 14-16 listopada 2002/pod red. B. Więcka. Łódź: Studio PoligrafCMYK, cop, pp. 115-119, 2002 (Polish).

[6] A. A. Al-Qudah, C. A. Mitchell, P. A. Biagioni, and D. L. Hussey, "Thermographic investigation of contemporary resincontaining dental materials," Journal of Dentistry, vol. 33, no. 7, pp. 593-602, 2005.

[7] D. L. Hussey, P. A. Biagioni, and P.-J. Lamey, “Thermographic measurement of temperature change during resin composite polymerization in vivo," Journal of Dentistry, vol. 23, no. 5, pp. 267-271, 1995.

[8] M. Hannig and B. Bott, "In-vitro pulp chamber temperature rise during composite resin polymerization with various lightcuring sources," Dental Materials, vol. 15, no. 4, pp. 275-281, 1999.

[9] D. A. Stewardson, A. C. C. Shortall, E. Harrington, and P. J. Lumley, "Thermal changes and cure depths associated with a high intensity light activation unit," Journal of Dentistry, vol. 32, no. 8, pp. 643-651, 2004.

[10] M. Dąbrowski, R. Dulski, M. Zaborowski, and S. Żmuda, "Evaluation of thermal effects during polymerization of restorative dental materials," Pomiary Automatyka Kontrola, vol. 9, no. 9, pp. 44-47, 2006 (Polish).

[11] M. Dąbrowski, R. Dulski, M. Zaborowski, and M. Aluchna, "Examination of temperature change of composite dentistry materials during polymeryzation," Prace Instytutu Elektrotechniki, vol. 234, pp. 97-104, 2008 (Polish).

[12] H. E. Goodis, J. M. White, B. Gamm, and L. Watanabe, "Pulp chamber temperature changes with visible-light-cured composites in vitro," Dental Materials, vol. 6, no. 2, pp. 99-102, 1990.

[13] L. Zach and G. Cohen, "Pulp response to externally applied heat," Oral Surgery, Oral Medicine, Oral Pathology, vol. 19, no. 4, pp. 515-530, 1965.

[14] E. Armellin, G. Bovesecchi, P. Coppa, G. Pasquantonio, and L. Cerroni, "LED curing lights and temperature changes in different tooth sites," BioMed Research International, vol. 2016, Article ID 1894672, 10 pages, 2016.

[15] A. Piplani, M. Suresh Sajjan, A. Ramaraju et al., "An in-vitro study to compare the temperature rise in the pulp chamber by direct method using three different provisional restorative materials," The Journal of Indian Prosthodontic Society, vol. 16, no. 1, pp. 36-41, 2016.

[16] V. Miletic, V. Ivanovic, B. Dzeletovic, and M. Lezaja, “Temperature changes in silorane-, ormocer-, and dimethacrylate-based composites and pulp chamber roof during light-curing," Journal of Esthetic and Restorative Dentistry, vol. 21, no. 2, pp. 122-131, 2009.

[17] R. J.-Y. Kim, S.-A. Son, J.-Y. Hwang, I.-B. Lee, and D.-G. Seo, "Comparison of photopolymerization temperature increases in internal and external positions of composite and tooth cavities in real time: incremental fillings of microhybrid composite vs. bulk filling of bulk fill composite," Journal of Dentistry, vol. 43, no. 9, pp. 1093-1098, 2015.

[18] C. J. Kleverlaan and A. J. de Gee, "Curing efficiency and heat generation of various resin composites cured with highintensity halogen lights," European Journal of Oral Sciences, vol. 112, no. 1, pp. 84-88, 2004.

[19] H.-S. Chang, K.-J. Cho, S.-J. Park et al., “Thermal analysis of bulk filled composite resin polymerization using various light curing modes according to the curing depth and approximation to the cavity wall," Journal of Applied Oral Science, vol. 21, no. 4, pp. 293-299, 2013.

[20] A. A. Al-Qudah, C. A. Mitchell, P. A. Biagioni, and D. L. Hussey, "Effect of composite shade, increment thickness and curing light on temperature rise during photocuring," Journal of Dentistry, vol. 35, no. 3, pp. 238-245, 2007.

[21] B. Więcek and G. De Mey, Termowizja w Podczerwieni. Podstawy i Zastosowania, Wydawnictwo PAK, Warszawa, Poland, 2011.

[22] N. K. Khaksaran, T. J. Kashi, V. Rakhshan, Z. S. Zeynolabedin, and H. Bagheri, "Kinetics of pulpal temperature rise during light curing of 6 bonding agents from different generations, using light emitting diode and quartz-tungsten-halogen units: an invitro simulation," Dental Research Journal, vol. 12, no. 2, pp. 173180, 2015.

[23] R. J.-Y. Kim, I.-B. Lee, J.-Y. Yoo et al., "Real-time analysis of temperature changes in composite increments and pulp chamber during photopolymerization," BioMed Research International, vol. 2015, Article ID 923808, 6 pages, 2015.

[24] P. Zaborowski, M. Dąbrowsk, and M. Radwan-Oczko, "Ocena wybranych właściwości fizycznych materiałów do wypełnień ubytków w zębach-badanie wstępne," Poradnik Stomatologiczny, vol. 5, pp. 180-185, 2011.

[25] A. Knežević, Z. Tarle, A. Meniga, J. Šutalo, G. Pichler, and M. Ristić, "Degree of conversion and temperature rise during 
polymerization of composite resin samples with blue diodes," Journal of Oral Rehabilitation, vol. 28, no. 6, pp. 586-591, 2001.

[26] D. S. Cobb, D. N. Dederich, and T. V. Gardner, "In vitro temperature change at the dentin/pulpal interface by using conventional visible light versus argon laser," Lasers in Surgery and Medicine, vol. 26, no. 4, pp. 386-397, 2000.

[27] A. C. Shortall and E. Harrington, "Temperature rise during polymerization of light-activated resin composites," Journal of Oral Rehabilitation, vol. 25, no. 12, pp. 908-913, 1998. 

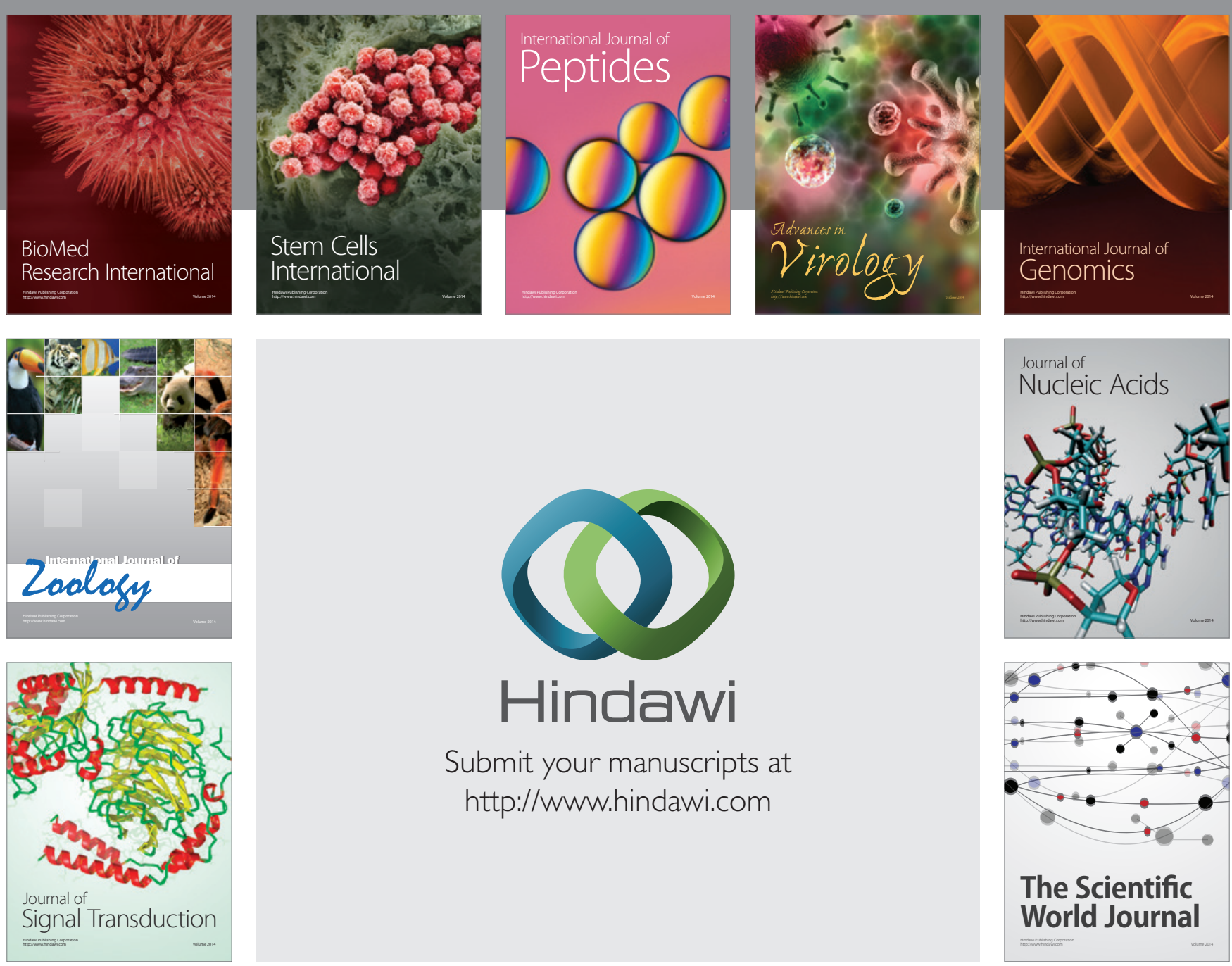

Submit your manuscripts at

http://www.hindawi.com
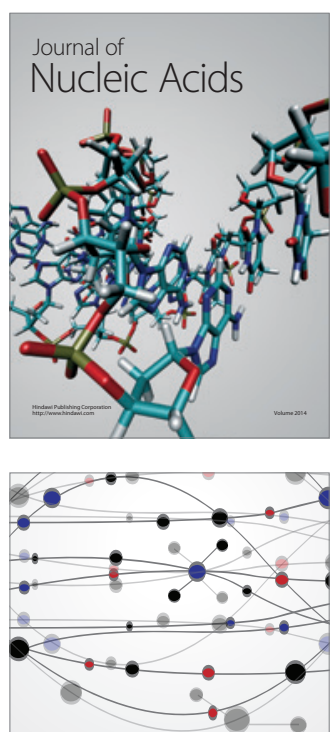

The Scientific World Journal
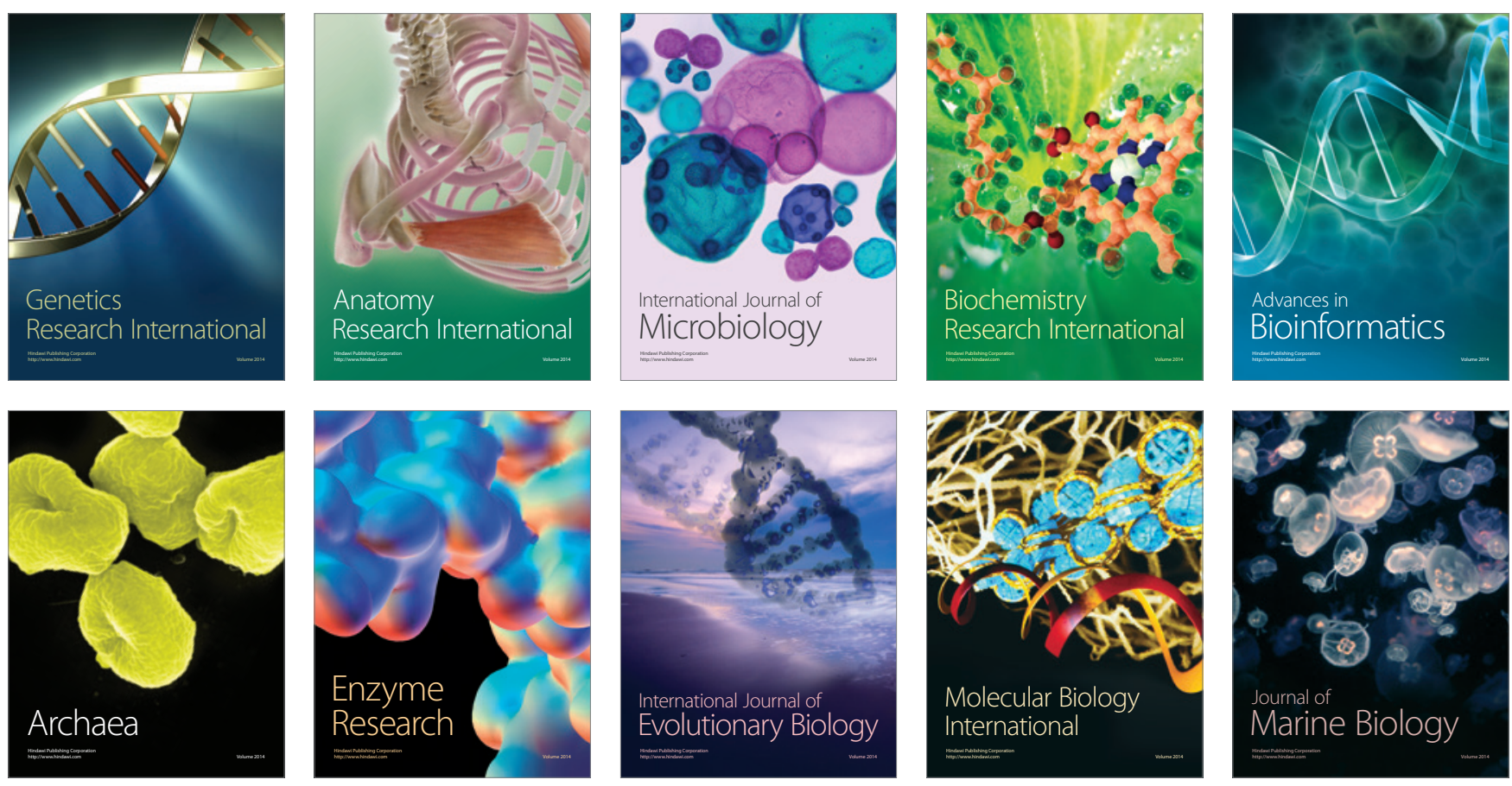